\title{
Characterisation of purified protease from Bacillus subtilis BS166
}

\author{
Ranganathan Kapilan* \\ Department of Botany, Faculty of Science, University of Jaffna, Jaffna.
}

Revised: 22 October 2015; Accepted: 27 November 2015

\begin{abstract}
Proteases are enzymes that break up the peptide bonds of proteins to release amino acids. Proteases showing better stability at alkaline $\mathrm{pH}$ and higher temperatures have potential applications in several industrial processes. The present study was aimed at determining the kinetic properties of the partially purified protease obtained from Bacillus subtilis BS166. Bacillus subtilis BS166 can produce protease above $30{ }^{\circ} \mathrm{C}$ and at $\mathrm{pH}$ 7.0. The protease was extracted with $0.1 \mathrm{M}$ phosphate buffer of $\mathrm{pH} 7.0$ and precipitated with ammonium sulfate. The activity of the purified protease was higher at $\mathrm{pH}$ 9.0 and $40{ }^{\circ} \mathrm{C}$ and showed zero order kinetics for 10 minutes. When the optimum enzyme concentration was $95.52 \mu \mathrm{g}$, a straight line was obtained in the Lineweaver-Burk plot graph. Michaelis constant for the purified enzyme was $50.9 \mu \mathrm{M}$ and Vmax was 2833.4 pmolmin $^{-1}$ at $\mathrm{pH} 9.0$ and $40^{\circ} \mathrm{C}$.
\end{abstract}

Keywords: Bacillus subtilis BS166, Michaelis constant, protease, Vmax.

\section{INTRODUCTION}

Proteases are one of the important groups of industryvaluable enzymes that contribute more in the total enzyme market (Schallmey et al., 2004). Proteases (peptidases or proteinases) are enzymes that perform proteolysis. Protein is catabolised by hydrolysis of the peptide bonds that link adjacent amino acids together in the polypeptide chain that forms protein (Paudel \& Parajuli, 1999). Proteases control the activity of a variety of proteins, modulate protein-protein interactions, synthesise new molecules, activate cellular information and create molecular signals. Because of these multiple functions, proteases are involved in DNA replication and transcription, cell proliferation, morphogenesis and heat responses of unfolded proteins, angiogenesis, fertilisation, ovulation, healing of wounds, stem cell mobilisation, blood coagulation, inflammation, haemostasis, immunity, necrosis, senescence and defence. Consistent with these important contributions of proteases in cells and survival and death of all organisms, alterations in proteolytic enzyme systems underlie multiple pathological diseases (Christeller, 2005). Many proteases are used as potential drug targets and as biological markers. Proteases are widely distributed in plants, animals and microbes. In higher organisms, almost $2 \%$ of the genes code for proteases. The proteases are useful in various ways and their applications in life show an increasing trend. Proteases are used in degumming of silk goods, manufacturing liquid glue, preparation of cheese, medicines and cosmetics, tenderisation of meat and in agriculture as growth promoters. The major sources of these proteases are microbes.

Bacillus species produce a huge variety of extracellular enzymes such as protease, amylase and xylanase, which are of great industrial importance. Bacterial enzymes are thermostable than fungal proteases. Members of the genus Bacillus are heterogeneous and are versatile in their adaptability to the environment. There are a lot of factors that influence metabolic processes and enzyme synthesis and function. There is a huge expectation on the thermophilic and extremely thermophilic microorganisms and their enzymes (Grubb \& Lofberg, 1982). Bacillus subtilis BS166 is a Gram-positive, rod shaped, endospore-forming bacteria. It is catalase positive and commonly found in soil including low nutrient soil. Unlike several other well-known species, Bacillus subtilis BS166 has been classified as an obligate aerobe. Due to its association with soil particles, it could be transferred to plants, food, animals and even marine and freshwater habitats (Barrow \& Feltham, 1993; Madigan \& Martinko, 2005). 
Proteases from diverse Bacillus species have been extracted, purified and characterised and the substrate specificity, thermal stability, $\mathrm{pH}$ stability, downstream processing procedures and low cost have been investigated (Hadder et al., 2009). Such properties increase the utility of proteases for industrial applications. Proteases showing better stability at alkaline $\mathrm{pH}$ and higher temperatures have potential applications in several industrial processes (Schallmey et al., 2004). For large scale production of proteases in the industrial practice, scientists are looking for microbes that can produce alkaline and thermostable protease enzymes at a wide range of $\mathrm{pH}$ values. These microbes can also be used in biotechnological applications. Theromostability and alkalinic nature of the protease enzyme produced by Bacillus subtilis BS166 strain is not known and these properties need to be investigated. Therefore the objective of this research was to purify protease from Bacillus subtilis BS166 strain by ammonium sulfate precipitation and to study the kinetic properties of the enzyme.

\section{METHODOLOGY}

\section{Source of Bacillus subtilis}

The culture of Bacillus subtilis BS166 strain was provided by Dr Sandeepa Kanitkar, Department of Biological Science, University of British Columbia, Canada.

\section{Initial screening of growth and potential protease} production by Bacillus subtilis BS166 strain

The pure culture of Bacillus subtilis BS166 strain was screened for growth and the production of extracellular protease using skim milk agar plates. The pure cultures were streaked as a line on the skim milk agar plates and the plates were incubated at $37^{\circ} \mathrm{C}$ for $24 \mathrm{hrs}$.

\section{Protease production by Bacillus subtilis BS166}

Ten milliliters of an overnight culture of Bacillus subtilis BS166 was used to inoculate a 0.5 L Erlenmyer flask containing $490 \mathrm{~mL}$ aliquots of liquid production medium, which consist of glucose $0.5 \%$ (wt/vol), peptone $0.75 \%$ (wt/vol), $\mathrm{KH}_{2} \mathrm{PO}_{4} 0.5 \%$ (wt/vol), $\mathrm{MgSO}_{4} .7 \mathrm{H}_{2} \mathrm{O} 0.05 \%$ (wt/vol) and $\mathrm{FeSO}_{4} .5 \mathrm{H}_{2} \mathrm{O} 0.01 \%$ (wt/vol) at $\mathrm{pH} 7.0$ and maintained at $37{ }^{\circ} \mathrm{C}$ for $24 \mathrm{hrs}$ in a shaker incubator. The $\mathrm{pH}$ of the medium was adjusted by $1 \mathrm{~N} \mathrm{NaOH}$ or $1 \mathrm{~N}$ $\mathrm{HCl}$. After the completion of fermentation, the whole fermentation broth was centrifuged at $15,000 \mathrm{rpm}$ at $4{ }^{\circ} \mathrm{C}$ for $15 \mathrm{~min}$ and the clear supernatant was recovered. The supernatant was used as the crude enzyme for further studies.

\section{Analytical methods - Bradford assay of crude extract}

A working solution of bovine serum albumin (BSA) was made by diluting the standard BSA solution of $1 \mathrm{mg} / \mathrm{mL}$ to $0.1 \mathrm{mg} / \mathrm{mL}$. In 5 test tubes $200 \mu \mathrm{L}, 400 \mu \mathrm{L}, 600 \mu \mathrm{L}$, $800 \mu \mathrm{L}$ and $1 \mathrm{~mL}$ of the BSA working solution was taken and named 1-5. The volume was maintained at $1 \mathrm{~mL}$ by adding distilled water. A blank was set with only distilled water. $500 \mu \mathrm{L}$ of the crude extract was taken for Bradford assay and $500 \mu \mathrm{L}$ of sterile distilled water was added to make the final volume of $1 \mathrm{~mL}$. Then $5 \mathrm{~mL}$ of the Bradford reagent was added and after 5 min of incubation, the absorbance was measured with the spectrophotometer at $595 \mathrm{~nm} .50 \mu \mathrm{L}$ of BSA $(1 \mathrm{mg} / \mathrm{mL})$ standard solution and around $20 \mu \mathrm{L}$ of crude extract was taken to calculate the proteolytic activity of the crude enzyme. The BSA and enzyme were mixed and the volume was maintained at $200 \mu \mathrm{L}$ by the addition of phosphate buffer. The mixture was incubated for $30 \mathrm{~min}$ and $2.3 \mathrm{~mL}$ of the Bradford reagent was added. After $5 \mathrm{~min}$, the absorbance was measured with the spectrophotometer at $595 \mathrm{~nm}$ against blank with reference to two controls: enzyme only and BSA only. The activity of protease was calculated with the following equation (Bradford, 1976). One unit of protease activity is defined as the amount of enzyme that produces $1 \mu \mathrm{mol}$ of tyrosine per minute at $\mathrm{pH} 9.0$ and $60{ }^{\circ} \mathrm{C}$.

$\begin{aligned} & \text { Protease } \\ & \text { activity }\end{aligned}=\frac{\begin{array}{c}\text { Amount of BSA } \\ \text { chopped }(\mu \mathrm{g})\end{array} \times \begin{array}{c}\text { Volume of } \\ \text { enzyme }(\mathrm{mL})\end{array}}{\text { Incubation time }(\mathrm{min})}$

\section{Precipitation by ammonium sulfate and dialysis}

The culture supernatant was taken in a conical flask. Solid ammonium sulfate was gradually added to the conical flask with stirring using a sterile magnetic stirrer, to make up to $70 \%$ saturation. Then it was kept in the refrigerator for complete precipitation. The protein precipitate obtained was separated by centrifugation at $15,000 \mathrm{rpm}$ for $15 \mathrm{~min}$ at $4{ }^{\circ} \mathrm{C}$. The supernatant was discarded and the pellet obtained was dissolved in $15 \mathrm{~mL}$ of $0.1 \mathrm{M}$ phosphate buffer and dialysed overnight against $0.1 \mathrm{M}$ phosphate buffer of $\mathrm{pH}$ 7.0. Salt containment of the solution was removed by overnight dialysis in $0.1 \mathrm{M}$ phosphate buffer. The protease activity was determined by using standard Bradford assay method (Bradford, 1976). 


\section{Characterisation of partially purified protease}

\section{Effect of $p H$}

The effect of $\mathrm{pH}$ on protease activity was measured in buffers at different $\mathrm{pH}$ values [Citrate-phosphate buffer ( $\mathrm{pH} 3.0$ to 6.0), sodium phosphate buffer ( $\mathrm{pH} 7.0$ ), Tris buffer ( $\mathrm{pH}, 8.0$ and 9.0), carbonate-bicarbonate buffer (pH 10.0 - 12.0)] and incubated at optimised conditions. Thirty microliters of the enzyme extract was mixed with $50 \mu \mathrm{L}$ of BSA standard solution $(1 \mathrm{mg} / \mathrm{mL})$ and the volume was maintained at $200 \mu \mathrm{L}$ by adding different buffers of different $\mathrm{pH}$. After incubation for $30 \mathrm{~min}$, $2.3 \mathrm{~mL}$ of Bradford reagent was added and the protease activity was determined by using standard Bradford assay method (Bradford, 1976).

\section{Effect of temperature}

The effect of temperature on the protease activity of $70 \%$ ammonium sulfate precipitated extracts was characterised at different temperatures. For different temperatures the refrigerator $\left(4^{\circ} \mathrm{C}\right)$, room temperature $\left(20^{\circ} \mathrm{C}\right)$, incubator $\left(40{ }^{\circ} \mathrm{C}\right)$ and oven $\left(60^{\circ} \mathrm{C}, 80^{\circ} \mathrm{C}, 100^{\circ} \mathrm{C}\right)$ were used. Thirty microliters of enzyme extract was mixed with $50 \mu \mathrm{L}$ of BSA standard solution and the volume was maintained at $200 \mu \mathrm{L}$ by adding phosphate buffer and the protease activity was determined by using standard Bradford assay method (Bradford, 1976).

\section{Effect of enzyme concentration}

Different concentrations of the protease enzyme (10, $20,40,60,80,100$ and $\left.120 \mathrm{gL}^{-1}\right)$ were prepared with phosphate buffer $(\mathrm{pH} 7.0,0.1 \mathrm{M})$ at optimum $\mathrm{pH}$ and they were mixed with $50 \mu \mathrm{g}$ of BSA standard solution to react at the optimum temperature for optimised time. The protease enzyme activity was determined by using standard Bradford assay method (Bradford, 1976).

\section{Effect of substrate concentration}

Different concentrations of the BSA solution was prepared $\left(20,40,60,80\right.$, and $\left.100 \mu \mathrm{gL}^{-1}\right)$ with phosphate buffer
$(\mathrm{pH} 7.0,0.1 \mathrm{M}$ ) at optimum $\mathrm{pH}$ and they were allowed to react with the diluted enzyme at the optimum temperature for optimised time. The protease enzyme activity was determined by using standard Bradford assay method (Bradford, 1976). The Michelis constant and Vmax for the purified protease were calculated.

\section{RESULTS}

\section{Confirmation of the Bacillus subtilis BS166 strain utilising protein}

The pure culture of Bacillus subtilis BS166 strain produced clear zones in the skim milk agar plates after 24 hours.

\section{Ammonium sulfate salt precipitation of crude extract}

The protease enzyme activity of the crude enzyme was 69.6 pmolmin $^{-1} \mathrm{~mL}^{-1}$. To the crude protease, solid $\left(\mathrm{NH}_{4}\right)_{2} \mathrm{SO}_{4}$ was added. Precipitation of the protein increased but the specific activity increased with $\left(\mathrm{NH}_{4}\right)_{2} \mathrm{SO}_{4}$ saturation (Table 2). The protease activity of $70 \%$ ammonium sulfate precipitated extract was 432.5 pmolmin $^{-1} \mathrm{~mL}^{-1}$ (Table 1). The crude enzyme sample precipitated with $70 \%\left(\mathrm{NH}_{4}\right)_{2} \mathrm{SO}_{4}$ saturation showed the highest specific activity (305.87 pmolmin $\left.^{-1} \mathrm{~mL}^{-1}\right)$ (Table 2).

Table 1: Protease activities of crude and ammonium sulphate precipitated extract

\begin{tabular}{lccc}
\hline & $\begin{array}{c}\text { Remained } \\
\text { BSA in } \mu \mathrm{g}\end{array}$ & $\begin{array}{c}\text { Chopped } \\
\text { BSA in } \mu \mathrm{g}\end{array}$ & $\begin{array}{c}\text { Activity in } \\
\mathrm{pmolmin}^{-1} \mathrm{~mL}^{-1}\end{array}$ \\
\hline Crude & 44.2 & 5.3 & 69.6 \\
$\begin{array}{l}\text { After ammonium } \\
\text { sulphate } \\
\text { purification }\end{array}$ & 22.4 & 26.6 & 432.5 \\
\hline
\end{tabular}

Table 2: Summary of protein and protease purification using ammonium sulphate

\begin{tabular}{lcccccccc}
\hline & $\begin{array}{c}\text { Volume } \\
(\mathrm{mL})\end{array}$ & $\begin{array}{c}\text { Protein } \\
\text { concentration } \\
(\mathrm{mg} / \mathrm{mL})\end{array}$ & $\begin{array}{c}\text { Total } \\
\text { protein } \\
(\mathrm{mg})\end{array}$ & $\begin{array}{c}\text { Activity } \\
\left(\mathrm{pmolmin}^{-1}\right. \\
\left.\mathrm{mL}^{-1}\right)\end{array}$ & $\begin{array}{c}\text { Total activity } \\
\left(\mathrm{pmolmin}^{-1}\right. \\
\left.\mathrm{mL}^{-1}\right)\end{array}$ & $\begin{array}{c}\text { Specific } \\
\text { activity } \\
\left(\mathrm{pmolmin}^{-1} \mathrm{~mL}^{-1}\right)\end{array}$ & $\begin{array}{c}\text { Purification } \\
\text { factor }\end{array}$ & $\begin{array}{c}\text { Overall } \\
\text { yield }(\%)\end{array}$ \\
\hline Crude & 420 & 0.302 & 126.84 & 69.6 & 29232 & 230.46 & 1 & 100 \\
Purified & 20 & 1.414 & 28.28 & 432.5 & 8650 & 305.87 & 1.33 & 29.6 \\
\hline
\end{tabular}




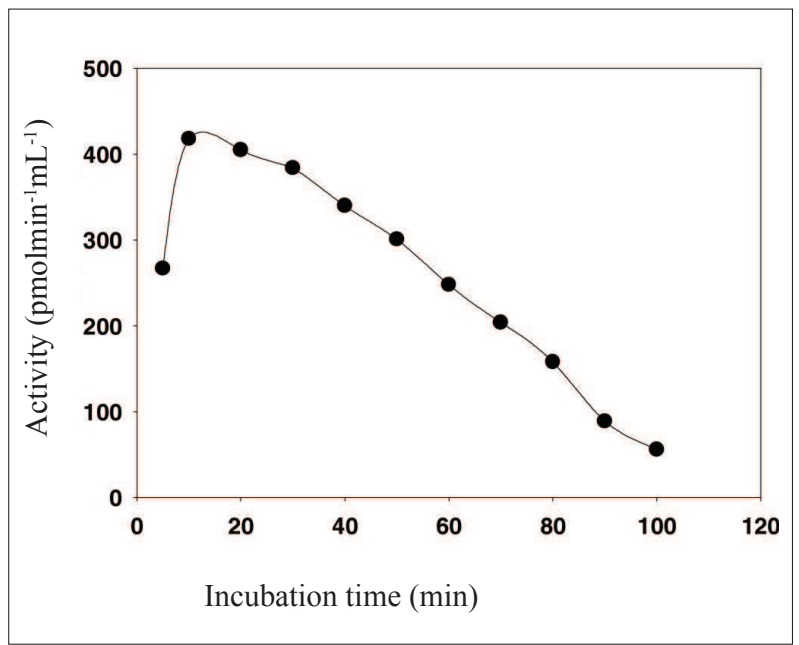

Figure 1: Effect of time of incubation on protease activity of $70 \%$ ammonium sulfate precipitated extract

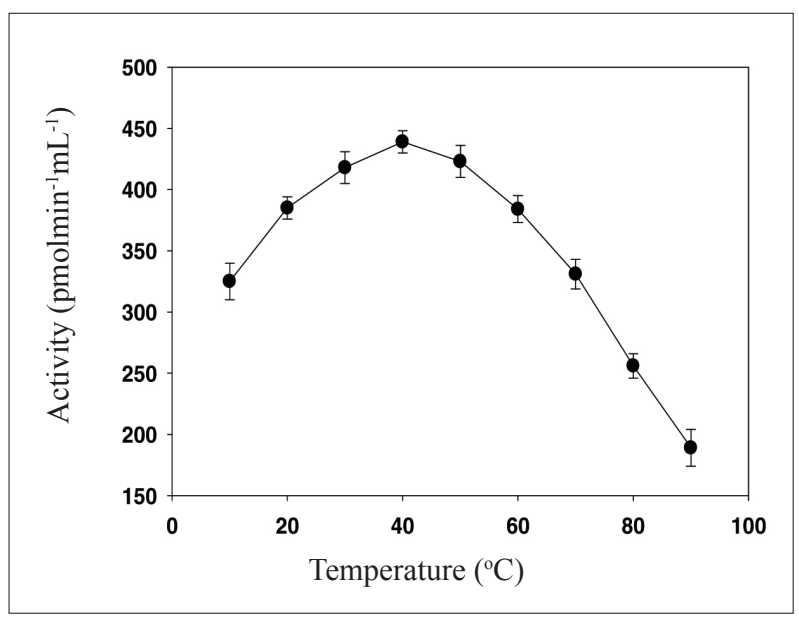

Figure 3: Effect of temperature on the purified protease activity

\section{Effect of time}

Purified protease showed zero order kinetics for 10 minutes (Figure 1). Therefore the incubation time for the kinetic studies was fixed as 5 minutes in the following experiments.

\section{Effect of pH}

When the $\mathrm{pH}$ varied from 3.0 to 12.0 , the activity of protease increased up to $\mathrm{pH} 9.0$ and further increase of the $\mathrm{pH}$ decreased the enzyme activity. Thus for further studies a $\mathrm{pH}$ of 9.0 was selected for purified protease. Protease enzyme showed activity between $\mathrm{pH} 3.0$ to 10.0 . However the enzyme showed $75 \%$ of its original activity at $\mathrm{pH}$ values

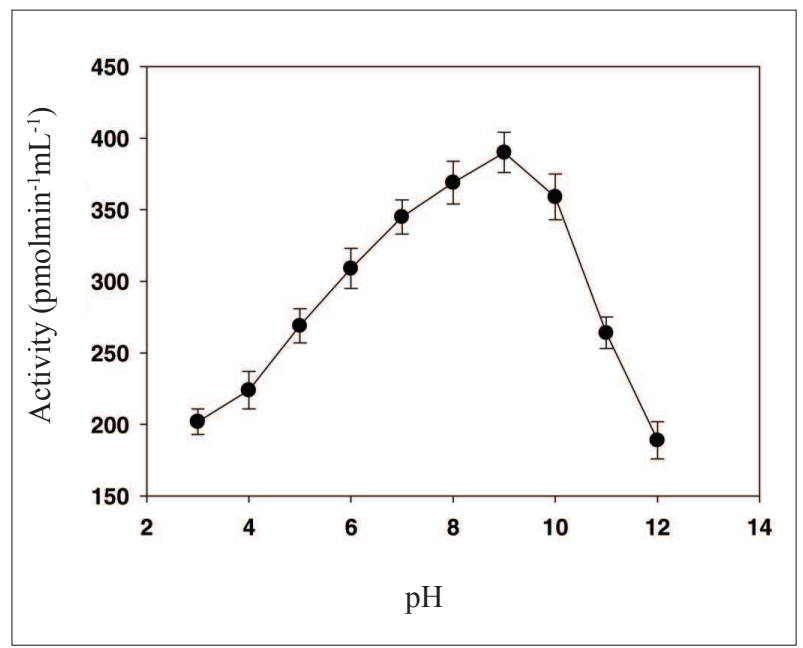

Figure 2: Effect of $\mathrm{pH}$ on protease activity of purified enzyme

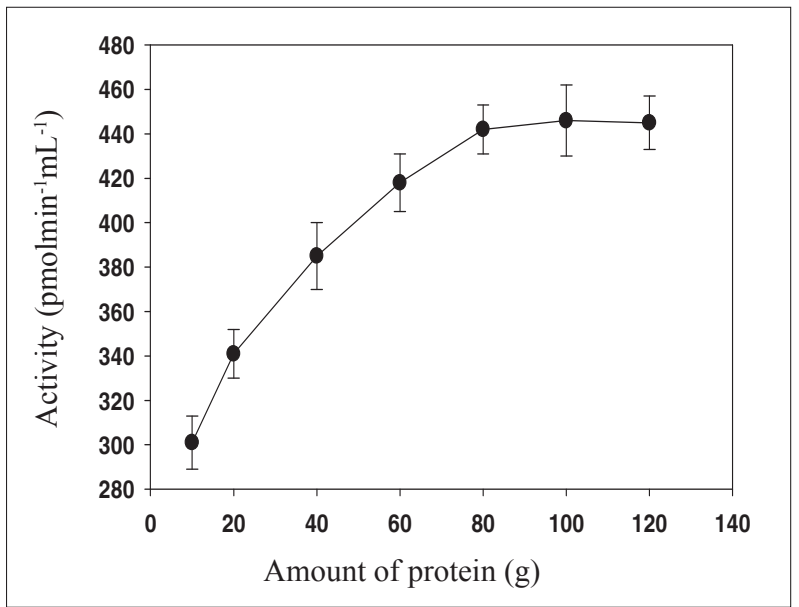

Figure 4: Effect of enzyme concentration on the purified protease activity

between 7.0 and 10.0 (Figure 2). Since the highest protease activity was obtained at $\mathrm{pH} 9.0$, it was selected for further studies.

\section{Effect of temperature}

The protease enzyme activity was assayed at different temperatures ranging from $40-90{ }^{\circ} \mathrm{C}$ at $\mathrm{pH} 9.0$. The activity of protease increased up to $40{ }^{\circ} \mathrm{C}$ and further increase in temperature decreased the enzyme activity. Purified protease exhibited a temperature profile with a sharp peak of maximal activity at $40{ }^{\circ} \mathrm{C}$ (442.98 pmolmin $^{-1} \mathrm{~mL}^{-1}$ ) and showed activity between $40-90{ }^{\circ} \mathrm{C}$ (Figure 3). 


\section{Effect of enzyme concentration}

The protease enzyme activity was assayed at different concentrations of the protein ranging from $10-120 \mathrm{gL}^{-1}$ at $\mathrm{pH} 9.0$ and a temperature of $40{ }^{\circ} \mathrm{C}$. The activity of protease increased up to $80 \mathrm{gL}^{-1}$ and further increase in the protein concentration decreased the enzyme activity (Figure 4).

\section{Effect of substrate concentration}

When the substrate concentration was increased from 20 $-100 \mu \mathrm{gL}^{-1}$ at $\mathrm{pH} 9.0$, the activity of protease increased up to $40 \mu \mathrm{gL}^{-1}$ and reached the maximum velocity at $60 \mu \mathrm{gL}^{-1}$ (Figure 5). Michaelis constant for the purified enzyme to soluble protein was $50.9 \mu \mathrm{M}$ and Vmax was 2833.4 pmolmin $^{-1}$ at $\mathrm{pH} 9.0$ and $40{ }^{\circ} \mathrm{C}$. Therefore $40 \mathrm{gL}^{-1}$ substrate concentration was used for the assay for further studies of enzyme activity.

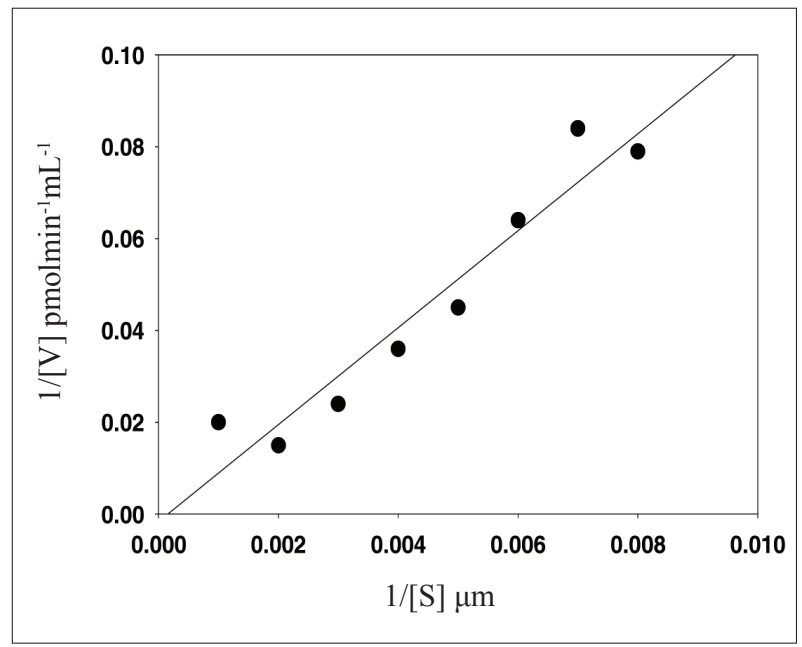

Figure 5: Lineweaver-Burk plot of the purified protease activity at $\mathrm{pH} 9.0$ and $40{ }^{\circ} \mathrm{C}$ using different concentrations of substrate

\section{DISCUSSION}

The pure culture of Bacillus subtilis BS166 strain produced clear zones in the skim milk agar plates after one day of incubation and this confirms the capacity of the strain to grow and utilise protein efficiently. Many types of salts have been employed for protein separation and purification through salting-out, and different proteins precipitate at different salt concentrations. Since $\left(\mathrm{NH}_{4}\right)_{2} \mathrm{SO}_{4}$ is a cost effective salt that is widely used for purification of proteases from bacteria, it was used in this study (Schallmey et al., 2004; Kapilan \&
Arasaratnam, 2014). Since $70 \%$ of ammonium sulfate saturation generally gives a higher yield than the other saturations, it was decided to use this saturation in the experiment (Kapilan, 2015). The specific activity of $70 \%$ ammonium sulfate precipitated fraction was significantly higher as compared to that of crude extract indicating purification of protease by 1.33 fold. The optimal $\mathrm{pH}$ of the protease was 9.0 and this suggests that the purified protease could be classified as an alkaline protease. The optimal temperature for protease activity was $40{ }^{\circ} \mathrm{C}$. The protease remained active even at $90^{\circ} \mathrm{C}$. Therefore it could be recommended that the purified protease is slightly thermophilic. The stability of the enzyme at higher temperatures might be due to the presence of thermotolerant residues in the purified extract. Sometimes ammonium sulfate might stimulate the formation of these residues. Some studies have reported the presence of higher amount of cysteine residues in some bacterial proteases (Murray et al., 1999). The initial increase in protease activity with temperature might be due to the collision between the enzyme and substrate. The increase in temperature causes increase in collision between enzymes and substrates (Mehrato et al., 1999). Beyond these optimal temperatures the activities were decreased as a result of denaturation of proteases due to heat (Karki et al., 2009).

An alkaline protease from $B$. subtilis was observed to be stable in the $\mathrm{pH}$ range of $8.0-11.0$ with the highest activity at pH 10.0 (Adinarayana et al., 2003). An extracellular alkaline protease from a thermophilic Bacillus strain has been purified using $80 \%$ ammonium sulfate precipitation followed by CM-cellulose and DEAE-cellulose ion exchange column chromatography that yielded 16.5 fold purification with the specific activity ranging from 417 to $6900 \mathrm{U} / \mathrm{mg}$ (Kamran et al., 2014; Hashem et al., 2015). The enzyme activity gradually reduces indicating inactivation of enzyme with time. A slightly linear line was obtained for the effect of enzyme concentration on protease activity indicating that the enzyme concentration enhances the rate of reaction. The linear line obtained for the effect of substrate concentration on protease activity indicated that the rate of reaction increases with the increase in substrate concentration. The low Michaelis constant $(\mathrm{Km})$ value of proteases indicated that the substrate is tightly bound to the enzyme.

\section{CONCLUSION}

The protease enzyme produced by pure Bacillus subtilis BS166 strain was purified by $70 \%$ of ammonium sulfate salt with a purification fold of 1.33 . The optimum activity of the purified protease was observed at $\mathrm{pH} 9.0$ and 
temperature $40{ }^{\circ} \mathrm{C}$. The purified protease showed zero order kinetics for 10 minutes and was active even at the temperature of $90{ }^{\circ} \mathrm{C}$. Michaelis constant of the purified enzyme to soluble protein was $50.9 \mu \mathrm{M}$ and Vmax was 2833.4 pmolmin $^{-1}$ at $\mathrm{pH} 9.0$ and $40{ }^{\circ} \mathrm{C}$.

\section{Acknowledgement}

The author expresses his gratitude to Dr Mohan Thiagarajah, Senior Research Associate, Department of Agricultural, Food and Nutritional Science, University of Alberta, Edmonton, Canada for the financial assistance and laboratory facilities.

\section{REFERENCES}

1. Adinarayana K., Ellaiah P. \& Prasad D.S. (2003). Purification and partial characterization of thermostable serine alkaline protease from a newly isolated Bacillus subtilis. AAPS Pharm SciTech 4(4): 440 - 448.

2. Barrow G.I. \& Feltham R.K.A. (1993). Staining of bacteria. Cowan and Steel's Manual for the Identification of Medical Bacteria (eds. G.I. Barrow \& R.K.A. Feltham), pp. 51 - 93. Cambridge University Press, UK.

3. Bradford M.M. (1976). A rapid and sensitive method for the quantitation of microgram quantities of protein utilizing the principle of protein-dye binding. Analytical Biochemistry 72: 248 - 254 .

4. Christeller J.T. (2005). Evolutionary mechanisms acting on proteinease inhibitor variability. FEBS Journal 272: $5710-5722$.

5. Grubb A. \& Lofberg H. (1982). Human adenophysis. Proceedings of the National Academy of Science of the United States of America 79: 3024 - 3027.

DOI: http://dx.doi.org/10.1073/pnas.79.9.3024

6. Haddar A., Agrebi R., Bougatef A., Hmidet N., SellamiKamoun A. \& Nasri M. (2009). Two detergent stable alkaline serine-proteases from Bacillus mojavensis A21: purification, characterization and potential application as a laundry detergent additive. Bioresource Technology 100: $3366-3373$.

DOI: http://dx.doi.org/10.1016/j.biortech.2009.01.061

7. Hashem A., Yesmin S., Pramanik M.K., Islam M.S., Rahim K.A., Salimullah M. \& Rahman M. (2015). Isolation, purification and characterization of an extracellular protease from a locally isolated Bacillus sphaericus SI-1. Bioresearch Communications 1(2): 87 - 92.

8. Kamran A., Bibi Z. \& Kamal M. (2014). Purification and molecular weight estimation of protease from a thermophilic Bacillus species. Pakistan Journal of Biochemistry and Molecular Biology 47(3 - 4): 155 - 157.

9. Kapilan R. \& Arasaratnam V. (2014). Characterization of xylanase produced by Bacillus pumilus. Journal of the National Science Foundation of Sri Lanka 42(4): 363 366. DOI: http://dx.doi.org/10.4038/jnsfsr.v42i4.7736

10. Kapilan R. (2015). Purification of xylanase from Bacillus subtilis BS166. Journal of Science 5(7): 511 - 515.

11. Karki S., Shakya R. \& Agrawal V.P. (2009). A novel class of protease from Choreospondias axillaris (Lapsi) leaves. International Journal of Life Science 3: 1 - 5. DOI: http://dx.doi.org/10.3126/ijls.v3i0.2301

12. Madigan M. \& Martinko J. (2005). Brock Biology of Microorganisms, $11^{\text {th }}$ edition. Prentice Hall, New York, USA.

13. Mehrato S., Pandey P.K., Gaur R. \& Darmwal N.S. (1999). The production of alkaline protease by a Bacillus species isolate. Bioresource Technology 67: 201 - 203.

14. Murray M.T. \& Pizzorno J.E. (eds.) (1999). Textbook of Natural Medicine, volume 1, $2^{\text {nd }}$ edition, pp. $619-622$. Churchill Livingstone, Edinburgh, England.

15. Paudel K.C. \& Parajuli D.P. (1999). Domestication and commercialization of Lapsi tree, a potential income source agroforestry in the middle hills of Nepal (Ministry of Science and Technology, Kathmandu, Nepal). Scientific World 1(1): 116 - 120.

16. Schallmey M., Singh A. \& Ward O.P. (2004). Developments in the use of Bacillus species for industrial production. Canadian Journal of Microbiology 50: 1 - 17. DOI: http://dx.doi.org/10.1139/w03-076 